\title{
Prostate Granular Cell Tumor
}

National Cancer Institute

\section{Source}

National Cancer Institute. Prostate Granular Cell Tumor. NCI Thesaurus. Code C161582.

A rare granular cell tumor that arises from the prostate gland. 